\title{
Modelling the Behavior of the Venture Capital Industry - Evidence from Egypt
}

\author{
Elsiefy, Elsayed \\ Qatar Faculty of Islamic Studies \\ Hamad Bin Khalifa University, Qatar Foundation- Qatar \\ Faculty of Commerce, Alexandria University, Egypt \\ Foudah, Mohammed \\ Qatar Faculty of Islamic Studies \\ Hamad Bin Khalifa University, Qatar Foundation- Qatar
}

\begin{abstract}
The objectives of this exploratory study are to investigate the behavior of the Venture Capital (VC) industry in Egypt, and to test whether there are relationships among the suggested dependent variables. We are studying the domestic VC industry through two dependent variables; i.e. 1) Patent Application Count representing the Innovation level, 2) Domestic Credit to Private Sector representing the private capital funding. Also we examine the international VC through the Foreign Direct Investment (FDI). We find positive significant relationship between the FDI and the Net Foreign Assets, the Gross Capital Formation and the Natural Gas Rents (\% of GDP), while there is a negative significant relationship with the Broad Money. For the Domestic Credit to Private Sector, we find a positive significant relationship with the Merchandise Exports, the FDI and the Manufacturing Value Added (\% of GDP), while we find a negative significant relationship with the Gross Savings (\% of GDP). For the Patent Applications Count, we find a significant positive relationship with the Domestic Credit to Private Sector, the FDI, the Education Expenditure, the Gross Savings, the Industry Value Added and the Primary Education (Pupils) while negative significant relationship with GDP. We find that FDI is positively and significantly affecting both other dependent variables while both; i.e. FDI and Domestic Credit to Private sector, are positively and significantly affecting the Patent Applications Count.
\end{abstract}

Keywords: Venture Capital, Islamic Finance, FDI, Egypt, Innovation, Patent, Domestic Credit, Education, Private Sector, SMEs

\section{INTRODUCTION}

The study is going to discuss the driving factors which significantly support and model the behavior of the domestic \& international VC industry (VC, henceforth). It is known by majority of academics and practitioners that the VC is mainly depending on the level of knowledge and innovation in the market and the level of available private capital being fed to this type of investment. The study suggests using Patent Applications Count representing the Innovation level, and Domestic Credit to Private Sector representing the private funding, in order to examine the domestic VC of Egypt, while to use Foreign Direct Investment (FDI) to examine the international VC of Egypt. The main target is to build significant representing models for the three dependent variables. Then we will check if the suggested dependent variables are affecting each other or not. 
For the last few decades, Small and Medium Enterprises (SMEs) have been proven that they are one of the major economic accelerators. (Thurik et al, 2002) show that higher level of entrepreneurship comes with higher rate of growth and lower unemployment. SMEs are usually facing challenges in raising the required funds in order to grow, so VC becomes the financial solution to their needs. (Musso and Schiavo, 2007) using panel data on French manufacturing firms, find that financial constraints significantly increase the probability of exiting the market while accessing the external financial resources has a positive effect on the firm's growth and employment. Also (Segarra and Teruel, 2009) find that Spanish young and small firms that are undercapitalized encounter greater barriers when attempting to access finances.

VC is a long-term risky and highly rewarded investment that may last up to 10 years and has the following characteristics:

1. VC is a non-bank financial intermediary between entrepreneurs and investors called General Partners (GPs). VCs are exchanging capital with equity stake in the firm which is receiving the funds. VC Firms usually operate within a partnership structure as they share capital as well as management efforts through participation in the company board. They raise capital from a limited partners (LPs) which include pension funds, insurance companies, foundations, endowments, and high-net-worth individuals.

2. VC firms play an active and important role in the portfolio monitoring of the companies whom receive the funds. They provide monitoring and consultancy services to these companies as well as availing their large business network that allow the company to attract further funds in its coming investment rounds; (Leslie and Wells; 1998). Also they provide the business knowledge and expertise to the companies in which they invest.

3. They are realizing their return of investment after exiting from the firm in which they have invested whether through M\&A or IPOs. VCs play an important role in IPOs as they are improving the market power of the firms in which they invest, (Chemmanur and Loutskina, 2005).

The definition of VC in the developed countries includes innovative technology-related investments, while in the developing countries it just includes all start-up and early-stage firm types. There are many papers that discuss the role of Innovation in spurring the VC industry. (Florida and Kenney; 1986) find that VC concentrates in areas where high technology-intensive small businesses exist. (Kortum and Lerner; 1998) find a significant positive relationship between VC volume in an industry and the rate of innovation or patenting in US between 1965 and 1992. They also find that VC investment is positively affecting the patenting rate 3 times more than R\&D investment does. (Ueda and Hirukawa; 2008) confirm the finding of (Kortum and Lerner, 1998) that VC has stronger positive impact on patents count than R\&D. (Ueda and Hirukawa; 2003) find a bidirectional positive relationship between the industrial innovation and the VC investment where both are affecting the performance of each other. In addition, (Bertoni et al; 2010) find positive impact of VC investments on firms' TFP (Total Factor Productivity). (Hellmann and Puri; 2000) show that innovation and business experience are both positively affecting the allocation of the VC investments. (Lerner; 2002) suggests that policy makers may focus on technologies or innovative opportunities which are not popular among the venture capitalists and provide follow-on funding to the already established firms when the in-flow of the VC funds is falling. While it is a better supportive for the VC industry to initiate programs that enhance the demand of these funds rather than just supplying the capital. In order to achieve this, incorporation of laws and tax policies should be taken into 
consideration which may have a substantial impact on the amount and flow-in of the VC as well as the yielded returns.

(Bertonia and Tykvováb, 2012) suggest that innovation output increases faster in companies financed by syndicates either governmental or private, as well as by private VC investors than in non-venture-backed ones. Also they suggest that the most supportive form is a heterogeneous syndicate (i.e., private and governmental syndicate investors) led by a private investor. (Chemmanur et al, 2013) find that Corporate VC-Backed (CVC) firms are more innovative than Independent VC-Backed (IVC) ones, as measured by their patenting outcome, although they are younger, riskier, and less profitable than IVC-backed firms. They return such conclusion to two possible mechanisms through which CVCs are able to better spur innovation; 1) the technological fit between CVCs' parent firms and the entrepreneurial firms backed by them, 2) the greater failure tolerance by CVCs relative to IVCs. (Elsiefy, 2013) finds a positive and a significant relation between the Innovation (measured by patents count) and the GDP per Capita, the General Government Expenditure and the Labor Participation Rate while Inflation is negatively significant with the Innovation. (Gourinchas and Rey, 2007) shows that U.S. has re-formed its international assets and liabilities position from a lending nature into a VC investment nature. (Chemmanur et al, 2010) find that entrepreneurial firms backed by syndicates composed of international and local venture capitalists are more successful than those backed by syndicates composed of purely international or purely local venture capitalists. They importantly find that local venture capitalists that have a greater extent of syndication experience with international venture capitalists have higher success rates than local venture capitalists that have a lesser extent of syndication experience with international venture capitalists. (Hazarika et al, 2009) finds that better legal rights is significantly affecting the likelihood of the Global VC success, also they find that the cultural differences between the international VCs and the local firms in which they invest are positively significant to the VC success.

From Islamic Finance point of view, VC is originally an Islamic Finance idea where the RabulMal; i.e. the investor, is providing the capital on a profit-loss sharing basis to the Mudhareb; i.e. the entrepreneur, for the purpose of conducting a new business opportunity in order to generate profit which will be shared based on a contractual agreement while losses to be distributed based on the capital share. Islamic Finance can re-promote the VC industry with the least required modification because VC falls within the Shariah compliance given the following considerations:

1. Permissibility of the capital sources. Capital should not include unlawful sources like pornography, drugs and weapon trading.

2. VC contracting should not involve usury; i.e. Riba, or unmanageable uncertainty level that may lead that a party will benefit on the loss of the other.

3. Permissibility of the business opportunity which will be undertaken. Actually, we may add that Islamic Finance has to consider the social benefits of the business opportunity during the due diligence being undertaken. It is the core role of Islamic Finance to look after the society's interests and needs in the first place prior to the maximization of profit.

On the other hand, Egypt is recognized as the birthplace of the modern Islamic Finance where Mit Ghamr is known World Wide as the first place of the first formal established Islamic Bank. Mit Ghamr savings bank was established by Dr. Ahmed El Naggar in 1963 and it was adopting the German savings bank under Shariah compliance. 
Later in 1980s, unregulated privately held investment companies, e.g. El Rayan Company and El Sherif Company, which claimed that they are Shariah compliant started to mobilize funds from the public with high attractive profit returns. Those companies have collapsed and resulted to affect negatively on the potential development and society acceptance of the Islamic Finance till the permission of the first full-fledged Islamic Bank in Egypt; i.e. Faisal Bank, in 1979.

It is one of the objectives of this study is to promote the modern VC industry as a potential Shariah compliant instrument which needs almost nothing to be modified in its structure.

\section{Egypt's Venture Capital Experience}

Egypt has an old VC experience back in the 18th century when the former French Diplomat Ferdinand de Lesseps convinced khedive of Egypt and Sudan at that time Sa'id Pasha to establish a company in order to conduct a project to construct Suez Canal in order to connect the Red Sea with the Mediterranean Sea. Ferdinand de Lesseps acted as the entrepreneur of the established portfolio company which has been named Suez Canal Company. The due diligence of the project has been undertaken between Paris and Cairo by International Commission for the piercing of the Isthmus of Suez which is a group of 13 experts from seven countries to examine the plans developed by Linant Pasha. The French government acted at that time as the VC investor. French government exited from the venture by liquidated its shares in Suez Canal Company to the public. Another exiting step has happened in 1956 when President Gamal Abdul Nasser announced that Suez Canal Company is an Egypt's property.

Recently Egypt has established several programs and initiatives in order to support the development of the VC industry:

- Ministry of Communication and Information Technology has founded the Information Technology Industry Development Agency (itida) in 2004 in order to promote the required ecosystem for the entrepreneurs through different government programs and initiatives with ICT leading companies

- American University in Cairo (AUC) has established the Entrepreneurship and Innovation Program (EIP) in 2010 in order to support and incubate the innovative business opportunities.

- A non-profitable organization named the Egyptian Private Equity Association has been founded in 2011 by group of business men and corporations in order to provide the support of the VC and PE in the region

- Egypt has only so far only TWO VC companies; i.e. IDEAVELOPERS and SAWARI VENTURES. IDEAVELOPERS has been founded at 2004 as a subsidiary of EFG Hermes PE. They invested \$25m in 17 companies out of \$50m Technology Development fund. SAWARI VENTURES has been founded in 2010 as an international VC firm which focuses in MENA region. It recently raised $\$ 50 \mathrm{~m}$ fund in the last Egyptian Economic Conference in Sharm El-Shiekh, dedicated to technology entrepreneurs.

- Also Egypt has a unique experience in the most recent VC fundraising style; i.e. The Crowdfunding. There are TWO Shariah Compliant crowdfunding companies working in Egypt and both have been founded in 2012; i.e. SHEKRA and YOMKEN. SHEKRA is an award winning Shariah Compliant crowdfunding firm which is working in a closed network of members in order to mitigate the adverse selection risk. YOMKEN is combining two concepts in one initiative; i.e. crowdfunding and open-innovation platform. 
The paper proceeds as follows: section 2 gives an overview on the motivation and objectives of the study from different angles and how it is relatively important. Section 3 demonstrates the literature review on the VC industry and shows the key determinants which are affecting it as well as its role in bringing up the economic growth. Then, section 4 shows the empirical analysis of the dependent variables and how we develop the resulting models. Section 5 concludes.

\section{Motivation of the Study}

\section{MOTIVATION AND OBJECTIVES OF THE STUDY}

Regional Economic Prospects report of European Bank for Reconstruction and Development (EBRD) - January 2015 states that the economic conditions have stabilized due to financial support from the GCC countries, however this financial support is in the form of central bank deposits which cannot contribute in the overall GDP. On the other hand, the report shows that the inflation remains high due to the high import prices and the currency depreciation. The fiscal deficit is above $12 \%$ of the GDP by end of $2013 / 2014$ fiscal year which is predicted to be lowered due to the fall of oil prices, which cannot be considered a real decrease due to improvement in the overall economy status. Similar facts are stated in EBRD Transition Report 2013 especially the reference to the low productivity as the economy needs to grow between 6 to 7 per cent annually, and the urgent need for good quality job creation in order to face the increasing unemployment rate; i.e. 13.2\%, moreover, more than 50\% of Egypt's labor force are working for low productivity sectors; i.e. agriculture and public sectors, while the employment share of private sector services had almost stagnated.

African Economic Outlook 2014 report also shows low economic indicators. Instability in the socio-economic conditions caused these low indicators; e.g. investment (14.2\% of GDP), exports (17.6\% of GDP), manufacturing (15.6\% of GDP), trade $(12.9 \%)$ and tourism $(3.2 \%)$. The report recommends implementing policies reforms which will encourage the SMEs to develop especially in the area of information and communication technology.

All above different economic indicators and reports show the urgent real need for an economic mentality transformation in order to improve the Egyptian economy through actual development which should be the outcome of real investments.

\section{Study Objectives}

The following points summarize the objectives of the study:

1. Develop a significant model for each suggested dependent variable.

2. Investigate whether there is relations between the suggested dependent variables if they affect each other models, so one can define a potential linkage between those economic indicators in order to form a strategy to improve the Egyptian VC industry

3. Draw the attention to the importance of the VC as a potential economic booster for the economy

4. Direct the attention of the Islamic Banking and Finance towards the VC industry as a Shariah Compliant business opportunity where Islamic Finance should contribute.

\section{LITERATURE REVIEW}

As VC industry aim to create new markets, it fosters enhancing the Employment rates in the country' economy. (Belke et al; 2003) find that supporting and sustaining technological innovation momentum in the country is one of the main sources of economic and employment growth. (Belke and Schaal; 2004) find that the unemployment rate is at its highest rates when the new innovative companies do not find the proper financing for their projects. (Feldmann; 
2010) shows that the more available VC in the market, the lower unemployment rate on the short-term and eventually lowering the long-term rate as well. (Ueda and Hirukawa; 2008) find that VC does not impact the Productivity Growth of the industry and the Productivity Efficiency of labor, it rather facilitates the entry of the new firms into the market, while the competitive pressure from these new firms may increase the patent propensity of the established firms. (Chemmanur et al; 2008) find that the VC-backed companies' performance is higher than the non-VC-backed ones. (Engel; 2002) finds that German new firms achieve 170\% point higher growth than non-backed VC firms. (Samila and Sorenson; 2011) suggest that VC financing is stimulating firms creation more than normal funding. (Peneder; 2010) finds that Austrian VC-backed companies grow faster in terms of employment and sales revenue than others while analysis proves that VC financing does not foster the innovation performance in the companies as the VC investment is initially selecting companies with above average level of innovation. (Gompers et al; 2006) show that entrepreneurs with a track record of success are more likely to succeed than first timers and those who have previously failed. They also find that funding by more experienced VC firms enhances the chance of success. Similarly, more experienced venture capitalists are able to identify and invest in first time entrepreneurs who are more likely to become serial entrepreneurs. This evidence would seem to suggest that prior success is a signal of quality or that VC firms add little value to talented and successful entrepreneurs. (Romain and Pottelsberghe; 2004) find that VC has higher impact on growth through the introduction of new products and business models and processes to the market. They also document that the VC has higher social benefits than other businesses and public R\&D.

(Romain and Pottelsberghe; 2003) find that interest rate is one of the influencing factors whereas short and long term interest rates have positive significant impact on the VC demand while the difference between the long-term and short-term (spread) has significant negative impact on the VC supply. They also find that VC demand is sensitive to the R\&D activities and expenditure as well as the available stock-of-knowledge in the market. The study shows that VC is positively and significantly pro-cyclical to the GDP growth rates. But the inflexibility of the labor market is mitigating the effect of the GDP growth rate on the VC supply. (Schertler; 2003) find that only interpretable results have been generated on studying VC early-stage financing rather than the broad definition of VC on expansion stages of the firms. (Gompers and Lerner; 1998) find that the demand side of the US state-level VC is positively and significantly affected by the spending of the R\&D on the industrial and academic levels, as the higher R\&D spending, the higher VC invested and the higher VC-backed companies created. (Schertler; 2003) finds that the level of VC investments positively depends on the stock market capitalization and the level of R\&D. (Jeng and Wells; 1998) find that IPOs are the strongest driver of VC cycles as well as Private Pension funds level which is a significant determinant over time however not across countries. They find that GDP and Market Capitalization Growth are not significant. They show that early-stage VC investing is negatively impacted by the labor market rigidities while later-stage are not. (Gilson and Black; 2004) argue that the VC industry can only be developed actively when the country's stock market is well-developed. (Cumming et al; 2004) indicate that the quality of the country's legal system is more centrally connected to facilitating the IPO exiting for VC-backed firm than the activeness of the country' stock market as it reduces the agency problems between investors and entrepreneurs. They have opposite opinion to (Gilson and Black; 1999) who argues that VC flourishes only when country's stock market is well-developed. 


\section{EMPIRICAL ANALYSIS}

The data of this study has been extracted from the World Bank indicators database; i.e. 1336 indicators, for Egypt. The data ranges from 1960 to 2014. The following sections will explain how we are going to define the working list of independent variables and the time series for the analysis. It is very important to identify a common time series for the 3 suggested dependent variables in order to avoid singular outliers.

The benchmark criteria of the model are based on the following two statistical values:

1. Adjusted-R2: It reflects the power of the developed model. The minimum accepted value is $70 \%$

2. Durbin-Watson: We are targeting to reach as close as possible to the value of 2 , however, the accepted values are laying between 1.85 and 2.15

\section{Study Approach}

The analysis will be conducted into two phases for each of the dependent variable:

1. Data preparation and filtration. This stage will result the final working independent variables set which will be associated with each dependent variable

a. Identify the time series for the dependent variables by selecting a continuous data series greater than or equal to 30 observations.

b. Identify the list of independent variables with valid data series within the same time series of the dependent variables

c. Execute a regression between each independent variable and each dependent variable individually in order to check if it is individually significant with the dependent variable and calculate the regression $\mathrm{R} 2$

d. Include only the independent variables which are individually significant with the dependent variable then sort them in a descending order according to their calculated $\mathrm{R} 2$ in the previous step.

2. Conducting Stepwise Multiple Regressions. This stage will result the final significant models for each dependent variable

a. The analysis will be done in several iterations in order to process as much possible combinations of independent variables.

b. The exit criteria from iterating on the independent variables is one of the following:

I. $\quad$ No more improvements to the Adjusted-R2 value.

II. A dependent variable occurs in the independent variables of the model of another dependent variable.

c. The following checks will be done once we add a new independent variable to the existing working model:

I. Variable must remain significant without affecting previously existing variables in the working model

II. If the new added independent variable is significant but turned one or more of the previously added variables into insignificant:

1. We will remove the turning variables one at a time in different combinations till we reach a significant state across all variables in the model

2. Then we generate the RESIDUAL series of both the new resulting model and the model resulted before the addition.

3. Then we compare the SKEWNESS and KURTOSIS values of both RESIDUAL series and we choose the model which has less SKEWNESS as well as has KURTOSIS close to the value of 3

III. If the new added independent variable is insignificant and turned one or more of the previously added variable into insignificant, we will keep removing the turning 
independent variables till we reach a significant state across all involved independent variables, then we repeat the steps mentioned in the previous point; i.e. point no. 2.c.ii. Otherwise the new added insignificant independent variable will be excluded.

\section{Data Set}

We find that the 3 variables are sharing a common time series between 1977 and 2012; i.e. 36 observations. Then we filter the whole extracted data to get the variables which have a full complete data series between 1977 and 2012 time series. The result of the later step is 495 independent variables. The following steps will be executed in order to prepare the 495 independent variables for the regression; this process will be repeated for each dependent variable:

Calculating R2 and the significant value; i.e. Prob., of each independent variable individually with the dependent variable.

1. The most important findings outcome of this step are:

a. Foreign Direct Investment as independent variable is individually significant with Domestic Credit to Private Sector. R2 value is 0.111465

b. Domestic Credit to Private Sector as independent variable is individually significant with Patent Applications Count. R2 value is 0.246457

2. The final counts of the individually significant independent variables are the following:
a. Foreign Direct Investment: 343 independent variables
b. Domestic Credit to Private Sector: 371 independent variables
c. Patent Applications Count: 405 independent variables

\section{Study Hypothesis}

Although the study approach is to run the regression analysis on all selected independent variables; however, we are expecting some of the following independent variables to occur in the final models of the dependent variables:

\begin{tabular}{|c|l|c|}
\hline \multicolumn{2}{|c|}{ Foreign Direct Investment" Expected Independent Variables and Relations } \\
\hline Hypothesis ID & \multicolumn{1}{|c|}{ Independent Variable } & Relation \\
\hline F-1 & Agriculture, value added & + \\
\hline F-2 & Broad money & + \\
\hline F-3 & Deposit interest rate (\%) & + \\
\hline F-4 & Exports of goods and services & + \\
\hline F-5 & GDP & + \\
\hline F-6 & Gross capital formation & + \\
\hline F-7 & Gross national income & + \\
\hline F-8 & Industry, value added & + \\
\hline F-9 & Natural gas rents (\% of GDP) & + \\
\hline F-10 & Net foreign assets & - \\
\hline F-11 & Net income from abroad & + \\
\hline F-12 & Net official development assistance received & + \\
\hline & &
\end{tabular}




\begin{tabular}{|c|c|c|}
\hline \multicolumn{3}{|c|}{$\begin{array}{c}\text { rchives of Business Research (ABR) } \\
\text { "Domestic Credit provided to Private Sector" Exsue 3, June-201 } \\
\text { Relations }\end{array}$} \\
\hline Hypothesis ID & Independent Variable & Relation \\
\hline D-1 & Agriculture, value added (current US\$) & + \\
\hline D-2 & Broad money (\% of GDP) & - \\
\hline D-3 & Exports of goods and services & + \\
\hline D-4 & Final consumption expenditure & + \\
\hline $\mathrm{D}-5$ & Foreign direct investment & + \\
\hline $\mathrm{D}-6$ & GDP per capita & - \\
\hline D-7 & Industry, value added & + \\
\hline $\mathrm{D}-8$ & Inflation & - \\
\hline $\mathrm{D}-9$ & Manufacturing, value added (\% of GDP) & + \\
\hline $\mathrm{D}-10$ & Merchandise exports by the reporting economy & + \\
\hline $\mathrm{D}-11$ & Net official flows from UN agencies & - \\
\hline $\mathrm{D}-12$ & Patent applications Count & + \\
\hline $\mathrm{D}-13$ & Population ages $15-64$ ( $\%$ of total) & - \\
\hline $\mathrm{D}-14$ & Population growth (annual \%) & - \\
\hline $\mathrm{D}-15$ & Real interest rate (\%) & - \\
\hline D-16 & Total natural resources rents (\% of GDP) & + \\
\hline $\mathrm{D}-17$ & Trade (\% of GDP) & + \\
\hline
\end{tabular}

\begin{tabular}{|c|l|c|}
\hline \multicolumn{2}{|c|}{ “Patent Applications Count" Expected Independent Variables and Relations } \\
\hline Hypothesis ID & \multicolumn{1}{|c|}{ Independent Variable } & Relation \\
\hline P-1 & Adjusted savings: education expenditure (\% of GNI) & + \\
\hline P-2 & Agriculture, value added (\% of GDP) & + \\
\hline P-3 & Broad money & - \\
\hline P-4 & Deposit interest rate (\%) & + \\
\hline P-5 & Domestic credit to private sector (\% of GDP) & + \\
\hline P-6 & Exports as a capacity to import & + \\
\hline P-7 & Final consumption expenditure & + \\
\hline P-8 & Foreign direct investment & + \\
\hline P-9 & GDP & \\
\hline
\end{tabular}


"Patent Applications Count" Expected Independent Variables and Relations

\begin{tabular}{|c|l|c|}
\hline Hypothesis ID & \multicolumn{1}{|c|}{ Independent Variable } & Relation \\
\hline $\mathrm{P}-10$ & GNI & + \\
\hline $\mathrm{P}-11$ & Gross savings & + \\
\hline $\mathrm{P}-12$ & Industry, value added (\% of GDP) & - \\
\hline $\mathrm{P}-13$ & Inflation, consumer prices (annual \%) & - \\
\hline $\mathrm{P}-14$ & Lending interest rate (\%) & + \\
\hline $\mathrm{P}-15$ & Manufacturing, value added & - \\
\hline $\mathrm{P}-16$ & Net official flows from UN agencies & - \\
\hline $\mathrm{P}-17$ & Net taxes on products & \\
\hline $\mathrm{P}-18$ & Population growth (annual \%) & \\
\hline
\end{tabular}

\section{Modelling Iterations \\ FDI}

\section{1st Iteration}

The 1st iteration has generated the model with all the variables are significant and the model statistics are matching the benchmark; i.e. Adjusted-R2 $=0.868085$ and Durbin-Watson $=$ 2.057585. We will perform regression 2nd iteration in order to improve the explanation power of the model. Another positive side of the model is that it achieves the statistical benchmarks with only 4 independent variables out of 343.

The model includes the following independent variables:

1. Net foreign assets (+ve relationship): It is matching hypothesis F-10. It refers to Foreign Assets less Foreign Liabilities owned by government monetary authorities. The more Foreign Assets than Liabilities, the more FDI.

2. Broad money (-ve relationship): It was expected to have a (+ve relationship) as per hypothesis F-2, however, Broad money is positively correlated with the Inflation. We checked the relation between the dependent variable and the "Inflation" independent variable and we found that it is not individually significant with "FDI" dependent variable and has (-ve relationship) with it. This explains the (-ve relationship) with the "Broad Money" variable which is positively correlated with the "Inflation".

3. Gross capital formation (+ve relationship): It matches hypothesis F-6. It is the net capital accumulation used for domestic investment in equipment, buildings and other intermediate goods for the sake of increasing the production of services and goods. The higher the Capital Formation, the faster economic growth as it leads to more production. Producing more goods and services can lead to an increase in national income levels. It does make sense to be positively significant with the dependent variable as it increases the ability for Foreign Investment by availing more national income.

4. Natural gas rents (\% of GDP) (+ve relationship): It matches as well F-9. It refers to the difference between the value of natural gas production at world prices and total domestic cost of production which contributes positively in the GDP and increases the government ability for foreign investment.

\section{2nd Iteration}


It has generated a model with all variables are significant and Adjusted-R2 value is 0.964647 and Durbin-Watson indicator is 2.004079. The model included the following independent variables:

1. Net foreign assets

2. Exports of goods and services

3. Imports of goods and services

4. Natural gas rents (\% of GDP)

5. Net income from abroad

6. Gross savings

7. Gross domestic savings

8. Age dependency ratio, young (\% of working-age population). It is not part of the hypothesis table of the dependent variable.

Although the statistical benchmark values resulted from the model are exceeding the targets, however we have the following concerns on the model:

1. The inclusion of both "Exports of Goods and Services" and "Imports of Goods and Services" is challenging in the real life in order to achieve the balance between both variables. So we replaced both variables with a new variable called "Exports as a capacity to import". However, the variable was insignificant and turned some of the previously added variable into insignificant. After applying step no. 2.c mentioned in the study approach section, we reached the model where the variable "Exports of goods and services" remained insignificant while all remaining variables are significant, so this variable has been removed.

2. "Gross savings" and "Gross domestic savings" may have similarity in terms of the economic indication meant by them, so they will removed from the model

3. "Age dependency ratio, young (\% of working-age population)" does not have economic explanation in the literature review in order to relate it with the dependent variable. So, the variable will be removed

We conclude to qualify 1st Iteration' model as it is matching the statistical benchmark with fewer variables than the other modified one. Also, the concerns we just highlighted regarding the independent variables in the last iteration may question the robustness of the model in the real application although it is statistically robust.

\section{Domestic Credit to Private Sector \\ 1st Iteration}

The initial model resulted from the 1st iteration with all variables are significant and the model statistical measures are fulfilling the benchmark; i.e. Adjusted-R2 $=0.900054$ and DurbinWatson $=1.891432$. The variables which are finally included in the model are:

1. Merchandise exports by the reporting economy (+ve relationship): It matches D-10 hypothesis. It shows positive relationship as it shows relation with international trading that affects the merchants' private income which accordingly increases their banking transactions. This increases the banks abilities to provide credits to their clients.

2. Inflation (-ve relationship): Of course the relation between the credit and inflation should be negative which shows a good sign for the robustness and accuracy of the data and the model. It matches hypothesis D-8.

3. Net ODA received (\% of GNI) (-ve relationship): It is not part of the related hypothesis table. It refers to the net development assistance loans and grants given by international agencies to low performing economies for the sake of improving the economic conditions and welfare. From one hand, it does make sense that it is negatively significant with the ability to provide credit as it reflects negative signs to the overall 
economic conditions. From the other hand, the independent variable is calculated with respect to the "GNI"; i.e. Gross National Income, that acts as the denominator in its calculation, while it has (+ve) relationship with the dependent variable. So, the more "GNI", the more "Domestic Credit to Private Sector", the less "Net ODA received" which explains the (-ve) relationship with the dependent variable.

4. Manufacturing, value added (\% of GDP) (+ve relationship): It matches D-9 hypothesis. It does make sense to have a positive relationship with the ability to provide credit, as the more manufacturing leads to better market movements and increases the abilities of the owner of those manufacturing to apply for credit as they have the good potential and ability to repay it.

\section{2nd Iteration}

During the iteration, only one variable got replaced which is the "Inflation" by the "Gross Savings (\% of GDP)" which is not part of the hypothesis table. The new independent variable shows (-ve) relationship with the dependent variable. This does not make sense, however, the dependent variable has (+ve) relationship with the "GDP" independent variable that works as the denominator of how "Gross Savings (\% of GDP)" independent variable is being calculated. The more "GDP", the more "Domestic Credit to Private Sector", the less calculated value of "Gross Savings (\% of GDP)" which may explain the (-ve) relationship with the dependent variable. However, the overall statistical measurements of the model got improved; i.e. Adjusted-R2 $=0.920536$ and Durbin-Watson $=2.017613$.

\section{3rd Iteration}

Interestingly, the "Net ODA received (\% of GNI)" independent variable has been replaced by the "Foreign Direct Investment". This is a very important note due to the following:

1. The overall model is significant with slight improvement in its statistical measures although the explanation power got reduced; i.e. Adjusted-R2 $=0.919304$ and DurbinWatson $=2.00389$.

2. The most important point is that the dependent variable "Foreign Direct Investment" is positively affecting the "Domestic Credit to Private Sector". This means that the more foreign investment, the more funding to be available domestically. This is due to the foreign currencies which will be credited in the domestic banks due to the international investments.

So, the final model that represents the variability of the "Domestic Credit to Private Sector" includes the following independent variables:

1. Merchandise exports by the reporting economy (+ve relationship)

2. Manufacturing, value added (\% of GDP) (+ve relationship)

3. Gross savings (\% of GDP) (-ve relationship)

4. Foreign direct investment (+ve relationship)

\section{Patent Applications Count \\ 1st Iteration}

The resulting model needs to be improved as the Durbin-Watson is at value 1.746237 which is out of the accepted benchmark range, however, the model has a very good explanation power; i.e. Adjusted-R2 $=0.973473$. The following are the independent variables of this model:

1. Domestic credit to private sector (\% of GDP) (+ve relationship): this is matching with hypothesis P-5 which is supporting the literature review which is confirming that VC funding; i.e. represented by "Domestic Credit to Private Sector" variable, is positively spurring the innovation represented by the "Patent Applications Count". 
2. Adjusted Savings: Education Expenditure (+ve relationship): this is also matching with hypothesis $\mathrm{P}-1$ as increasing the education expenditure is fostering the innovation level because it improving the stock of knowledge in the market. This is matching with the finding of (Aghion et al, 2009).

3. Gross Savings (+ve relationship): it was expected to have (-ve relationship) as the more Gross Savings, the less the momentum towards innovation. However, the (+ve relationship) can be explained that such type of surplus is increasing the $R \& D$ expenditure; however this cannot be validated due to the lack of $R \& D$ data.

4. Industry, value added (+ve relationship): it is not matching hypothesis P-12 as this independent variable is represented as a percentage of GDP while the variable suggested in the hypothesis is referring to the value itself. However, the new variable is confirming the finding of (Porter, 1990) as well as latest report of the World Economic Forum.

5. GDP (-ve relationship): it is not matching hypothesis P-9. This can be explained as that increasing the "GDP" level is correlating with higher level of society prosperity and government expenditure which relaxes the need for innovation. However, according to some papers (Elsiefy, 2013) and (Ulku, 2004) that innovation (measured through patent) is having significant positive with GDP per Capita.

6. Permanent cropland ( $\%$ of land area) (+ve relationship): the variable is not part of the hypothesis table and has not been mentioned in the literature review -up to the collected literature review- we will try to replace in the following iteration.

\section{2nd Iteration}

There couple of important findings in the resulting model of this iteration:

1. All variable are significant and the model statistical measures have been improved; i.e. Adjusted-R2 $=0.950226$ and Durbin-Watson $=2.100456$.

2. "Permanent cropland (\% of land area)" has been replaced by "Primary education, pupils" with (+ve relationship) which is not part of the hypothesis table. It is confirming the existence of the "Adjusted Savings: Education Expenditure". We will check the impact of both variables on the model if one of them can be removed.

a. We removed the "Adjusted Savings: Education Expenditure" independent variable from the model, however Durbin-Watson value has been dropped dramatically to 1.079287 . Moreover, two variables have been turned insignificant; i.e. "Foreign Direct Investment" and "Primary Education, Pupils". So, we will return "Adjusted savings: education expenditure" back to the model

b. Then, we removed "Primary education, pupils" from the model. However, the DurbinWatson went below the accepted benchmark at value of 1.800378 . So, we will return the variable to the model.

3. "Foreign Direct Investment" dependent variable has (+ve relationship) which makes this variable affecting both other dependent variables.

\section{CONCLUSION AND RECOMMENDATIONS}

The final models resulted from the study are the following:

1. Foreign Direct Investment $=-2080000000+0.030455^{*}$ NTFRNAST $0.008274 *$ BRDMNY $+0.243395^{*}$ GRSCPTFRM $+427000000 *$ NTGASRNT

2. Domestic Credit to Private Sector $=-4.168878+1.110207^{*}$ MRCHEXPRTS + 2.762344*MNFCVALAD - 0.685548*GRSSVNGGDP + 0.000000000446*FDI

3. Patent Application Count $=445.5192+16.97655^{*}$ DMSTCCRDTPRVT + $0.000000215^{*}$ EDUEXPNDT $+0.0000000315^{*}$ GRSSVNG $+0.000000115^{*}$ INDSTVALAD $0.0000000683 *$ GDPGRTH $+0.000104 *$ PRMEDUPPL $+0.0000000232 *$ FDI 
We found that "Foreign Direct Investment" is affecting significantly and positively both models of "Domestic Credit to Private Sector" and "Patent Applications Count" which gives an indication to the importance of the foreign investment to the domestic VC industry in Egypt. Moreover, we found that "Domestic Credit to Private Sector" is affecting significantly and positively the "Patent Application Count" which confirms the literature review which suggested that the private funding has positive significant impact on the innovation.

Comparing the resulting model of the Innovation level (Patent Applications Count) of this study with (Elsiefy, 2013) results, we conclude the following points:

1. The examined time series of this study is wider than Elsiefy's study; i.e. 1977:2012 compared to 1980:2010.

2. GDP per Capita has a positive significant relationship in Elsiefy's study while in this study, the GDP is showing negative significant relation ship

3. Elsiefy find a positive relation significant relationship with the government general expenditure while we find a positive relationship with the government education expenditure.

4. Other independent variables in Elsiefy's patent model do not appear in our patent model; i.e. Agriculture Materials Export and Inflation.

The following are recommendations for the potential further studies tackling relative subjects:

1. A more specialized and detailed information need to be collected through surveys and interviews with SMEs and entrepreneurs in Egypt in order to have their concerns and issues to be studied.

2. More broken-down type of information regarding the potential fields of innovation and patenting. This can be achieved by contacting the formal Egyptian authorities for the scientific studyes as they have better statistics on that regard

3. We need to include more indicators that reflect the social environment in order to study its effect on the results.

4. We need to emphasis on the role of Islamic Banking \& Finance to promote this promising industry as it actually falls into the social responsibility of the Islamic Banking \& Finance. (Mohammad and Shahwan, 2013) find that the Islamic banks are aiming towards profitoriented target rather than social-based objectives. Thus, they suggest that Islamic banks' objectives should promote the objectives of Islamic economics thus inculcating as well Maqasid al-Shariah in its holistic direction

5. Exiting in Islamic VC can be done through SUKUK along with the current exits; i.e. M\&A and IPOs.

6. Emphasizing the government role to support the VC industry, here are some examples to be considered but not to be limited to:

a. Development of the required regulations and policies that support the VC industry

b. Promoting the innovation levels starting from orienting the education towards it

c. Arranging regular national and international forums for the entrepreneurs to demonstrate their ideas and projects. This will encourage them to proceed with their projects

d. Nationalization of the VC industry by building a pool of private national fund for the sake of raising capital from the market by issuing Sukuk or shares. This pool of private funds should be created under the pure partnership basis where investors are sharing profit and loss according to the capital share. Such system required a transparent and robust regulations and supporting systems 
e. Increase the public awareness of the VC industry and create more government offices to provide the required technical assistance to the potential entrepreneurs in order to enter to and exit from the market.

f. Create a specific focused stock market in order to the investors to exit

\section{References}

Abou-Stait f. - 2005 - Are Exports the Engine of Economic Growth? An Application of Cointegration and Causality Analysis for Egypt - African Development Bank Economic Research Working Paper No 76

Aghion P., Boustan L., Hoxby C. and Vandenbussche J. - 2009 - The Causal Impact of Education on Economic Growth: Evidence from U.S. - Department of Economics, Harvard University

Alba P., Al-Shawarby S. and Iqbal f. - 2004 - Fiscal and Public Debt Sustainability in Egypt - Publication of the Egyptian Center of Economic Studies - Working Paper No. 38

Amit R., Brander J. and Zott c. - 1999 - Venture Capital Financing of Entrepreneurship: Theory, Empirical Evidence and a Research Agenda - The Blackwell Handbook of Entrepreneurship - eISBN: 9780631215738

Andrew Metrick A. and Yasuda A. - Venture Capital \& The Finance of Innovation - 2010 - 2nd edition - ISBN 978-0-47045470-1 - John Wiley \& Sons, Inc. - USA

Audretsch D., Thurik R., Verheul I., Wennekers S. - 2002 - Entrepreneurship - Determinants and Policy in a EuropeanU.S. Comparison - Kluwer Academic Publisher - Economics of Science, Technology and Innovation Vol. 27

Bakker M. r. and Gross A. - Development of Non-bank Financial Institutions and Capital Markets in European Union Accession Countries - 2004 - World Bank Working Paper no. 28

Bascha A. and Walz U. - 2002 - Financing practices in the German venture capital industry: An empirical assessment Center for Finance Studies, Universitat Frankfurt Working Paper no. 2002/08

Baygan G. - 2003 - Venture Capital Policy Review United States - OECD Science, Technology and Industry Working Papers 2003/12

Belke A. and Schaal A. - 2004 - Venture Capital Investment and Labor Market Performance: New Empirical Evidence for OECD Countries - IZA DP No. 1447

Belke A., Fehn R. and Foster N. - Does Venture Capital Investment Spur Employment Growth - 2003 - Center for European Policy Studies, WD No. 197

Bengtsson O. and Ravid A. - 2009 - The Geography of Venture Capital Contracts

Bertoni F. and Tykvová T. - 2012 - Which form of venture capital is most supportive of innovation? - ZEW Center for European Economic Research

Bertoni F., M. G., D’Adda D. and Grilli L. - 2011 - Venture Capital Financing and Growth of High-Tech Start Ups: Distangling treatment from selectio effects - Economics and Industrial Engineering - Politecnico di Milano - Research Policy - Volume 40, Issue 7, September 2011, Pages 1028-1043

Bertoni F., Colombo M. G., D'Adda D. and Grilli L. - 2009 - VC financing and the growth of new technology-based firms: correcting for sample self-selection - Department of Management, Economics and Industrial Engineering Politecnico di Milano

Brander A. and Bettignies H. - 2007 - Journal of Business Venturing - Volume no. 22 (2007), pages 808-832

Callahan. J and Muegge. S - 2002 - Venture Capital's Role in Innovation: Issues, Research and Stakeholder Interests Working paper at the Carleton University November 2002 Carleton University Ottawa, Ontario, Canada

Capizzi V., Giovannini R. and Pesic V. - 2014 - Determinant and Effects of VC on Italian SMEs

Chemmanur T. J., Hull T. J. And Krishnan K. - 2010 - Do Local and International Venture Capitalists Play Well Together? A Study of International Venture Capital Investments - Working Paper 
Chemmanur T. J., Loutskina E. and Tian X. - 2013 - Corporate Venture Capital, Value Creation, and Innovation - Working Paper, Boston College, University of Virginia, and Indiana University

Chemmanur T. J. and Loutskina E. - 2005 - The Role of Venture Capital Backing in Initial Public Offerings: Certification, Screening, or Market Power?

Chemmanur T. J., Krishnan, K., Nandy, D. - 2008 - How Does Venture Capital Financing Improve Efficiency in Private Firms? A Look beneath the Surface - Review of Financial Studies (RFS), 2011

Chemla G. - 2005 - The Determinants of Investment in Private Equity and Venture Capital: Evidence from American and Canadian Pension Funds

Chen H., Gompers P., Kovner A. and Lerner J. - 2009 - Buy Local? The Geography of Successful and Unsuccessful Venture Capital Expansion - Harvard Business School Finance Working Paper No. 1420371

Cherif M. and Gazdar K. - 2011 - What Drives Venture Capital Investments in Europe? New Results from a Panel Data Analysis - Journal of Applied Business and Economics vol. 12(3) 2011

Christensen J. - 2008 - The IPR System, Venture Capital and Capital Markets - Contributions and Distortions of Small Firm Innovation - DRUID, Copenhagen Business School, Department of Industrial Economics and Strategy/Aalborg University, Department of Business Studies - Working paper no. No 08-03

Cochrane J. H. - 2001 - The Risk and Return of Venture Capital - University of Chicago - Booth School of Business; Hoover Institution; National Bureau of Economic Research (NBER)

Croce a., Martí J. and Murtinu S. - 2013 - The Impact of Venture Capital on the Productivity Growth of European Entrepreneurial Firms: 'Screening' or 'Value added' Effect? - Journal of Business Venturing, Vol. 28, No. 4

Da Rin M. and Penas M. - 2007 - The Effect of Venture Capital on Innovation Strategies - National Bureau of Economic Research, Working Paper No. 13636

Divakaran S., McGinnis P. J. and Shariff M. - 2014 - Private equity and venture capital in smes in developing countries: the role for technical assistance - Policy Research working paper; no. WPS 6827

Dobronogov A. and Iqbal F. - 2004 - Economic Growth in Egypt: Constraints and Determinants - MENA Social and Economic Group - October 2004 - World Bank Working Paper No. 42

Dobronogov A. and Iqbal F. - 2005 - Economic Growth in Egypt: Constraints and Determinants - Middle East and North Africa Social and Economic Development Group - World Bank Working Papers

ECES - 2011 - Policy Viewpoint publication no. 27 - May 2011 - The Egyptian Economy Post-January 25: Challenges and Prospects

ECES - 2013 - Business Barometer 2013 - issue no. 13

ECES - 2013 - Egypt's Economic Profile and Statistics - Publication of the Egyptian Center of Economic Studies

ECES - 2013 - Performance and Expectations of the Egyptian Business Sector - Publication of the Egyptian Center of Economic Studies - Business Barometer - Issue No. 31

Elsiefy E. - 2013 - VENTURE CAPITAL: SURVEY OF THE ECONOMIC IMPACT AND THE DETERMINANTS - EMPIRICAL EVIDENCE FROM EGYPT - European Journal of Business and Social Sciences, Vol. 2, No.7 , pp 78-104 - ISSN: 2235 -767X

Enders K. - 2007 - Egypt-Searching for Binding Constraints on Growth - IMF Working Paper WP/07/57 - Middle East and Central Asia Department

Engel D. - 2002 - The impact of Venture Capital in Firm growth: an empirical investigation - Center for European Economic Research ZEW Discussion Paper No. 02-02

EVCA - 2013 - Exploring the impact of private equity on economic growth in Europe

F. Bertoni, M. Colombo, D. D'Adda and Murtinu - 2010 - Venture Capital Financing and Innovation in Europe New Technology-Based Firms: A longitudinal analysis on the role of the type of investor - paper contributed for the second conference of corporate R\&D, Concord-2010 
Fawzy S. - 2002 - Investment Policies and the Unemployment Problem in Egypt - Publication of the Egyptian Center of Economic Studies - Working Paper No. 68

Feldmann H. - 2010 - Venture Capital Availability and Labor Market Performance in Industrial Countries: Evidence Based on Survey Data - Department of Economics, University of Bath, UK, Working Paper 01/01

Fleming G., Schwienbacher A. and Cumming D. - Legality and Venture Capital Exits - 2006 - Journal of Corporate Finance, Vol. 12, pp. 214-245

FLORIDA R. and KENNEY M. - 1988 - VENTURE CAPITAL AND HIGH TECHNOLOGY ENTREPRENEURSHIP - Journal of Business Venturing 3, 301-319 0883-9029/88

Florida R. and Kenneyt M. - 1986 - Venture Capital, High Technology and Regional Development - Regional Studies working paper Vol. 22.1, pp. 3-48

Gilson J. and Black B. - 2004 - Does Venture Capital Require an Active Stock Market? - Journal of Applied Corporate Finance, pp. 36-48, Winter 1999

Gompers P. and Lerner J. - 1999 - What Drives Venture Capital Fundraising? - NBER Working Paper No. 6906 - Issued in January 1999 - Brookings Papers on Economic Activity: Macroeconomics (1998): 149-192

Gompers P., Kovner A., Lerner J. and Scharfstein D. - 2005 - Venture Capital Investment Cycles: The Impact of Public Markets - NBER Working Paper No. 11385 - Journal of Financial Economics, Elsevier, vol. 87(1), pages 1-23, January

Gompers P., Kovner a., Lerner J. and Scharfstein D. - 2006 - Skill vs. Luck in Entrepreneurship and Venture Capital: Evidence from Serial Entrepreneurs - "Performance Persistence in Entrepreneurship." Journal of Financial Economics 96 (2010): 18-32. Earlier version distributed as National Bureau of Economic Research Working Paper No. 12592 and Harvard Business School Working Paper No. 09-028

Groh a., Liechtenstein H. and Lieser K. - 2013 - The Venture Capital and Private Equity Country Attractiveness Index IESE Business School

GÜNAY S. - 2012 - DEVELOPMENT OF NEW ECONOMY VIA VENTURE CAPITAL AND INITIAL PUBLIC OFFERINGS IN TURKEY - Journal of Yasar University, 4(14), 2185-2203

Hegey U., Palominoz F. and Schwienbacher A. - 2008 - Venture Capital Performance: The Disparity between Europe and the United States

Hellmann, T. and Puri, M. - 2000 - The Interaction between Product Market and Financing Strategy: The Role of Venture Capital - Oxford University, the Review of Financial Studies

Helmy O. - 2005 - ICT Services without Border: an Opportunity for Egypt - The Egyptian Center for Economic Studies Working Paper no. 150

Helmy O. - 2009 - ICT SERVICES WITHOUT BORDERS: AN OPPORTUNITY FOR EGYPT? - Publication of the Egyptian Center of Economic Studies - Working Paper No. 150

Herrera S., Selim H., Youssef H. and Zaki C. - 2010 - Egypt beyond the Crisis Medium-Term Challenges for Sustained Growth - Policy Research Working Paper 5451 - The World Bank - Middle East and North Africa Region - Poverty Reduction and Economic Management

Higashide H. and Birley S. - 2002 - The consequences of conflict between the venture capitalist and the entrepreneurial team in the United Kingdom from the perspective of the venture capitalist - Journal of Business Venturing 17 - 2002 59-81

Hirsch J. and Sharifzadeh A. - 2009 - Geography and Contract Design in the Venture Capital Industry - Regional Comparative Advantage and Knowledge Based Entrepreneurship Working paper no. 066

Hirukawa M. and Ueda M. - 2008 - Venture Capital and Industrial Innovation - Discussion Papers in its series CEPR Discussion Papers with number 7089

IESE Business School - 2013 - The Venture Capital and Private Equity Country Attractiveness Index

Kandil M. - 2011 - The Egyptian Economy Post-January 25: Challenges and Prospects - Publication of the Egyptian Center of Economic Studies - Policy Viewpoint Issue No. 27 
Elsiefy, E., \& Foudah, M. (2015). Modelling the Behavior of the Venture Capital Industry - Evidence from Egypt. Archives of Business Research, 3(3), $31-49$

Kaplan S. and Strömberg P. - 2000 - How Do Venture Capitalists Choose Investments? - First Draft: August 2000 University of Chicago

Karadeniz E. and Ozdemir O. - 2009 - Entrepreneurial Activities in Turkey: An International Comparison Using GEM Data - Management and Administration Research Center, METU - Working Paper No. 2009-01

Kelly R. - 2011 - The Performance and Prospects of European Venture Capital - European Investment Fund Research and Market Analysis - Working Paper 2011/09

Koh W. and Koh F. - 2002 - Venture Capital and Economic Growth: An Industry Overview and Singapore's Experience Singapore Management University, School of Economics and Social Sciences, Working Paper No. 21-2002

Kortum S. and Lerner J. - 2000 - Assessing the contribution of venture capital to innovation - RAND Journal of Economics Vol. 31, No. 4, winter 2000pp. 674-692

Kortum S. and Lerner J. - 1998 - Does Venture Capital Spur Innovation? - National Bureau of Economic Research, Working Paper No. 6848

Koskinen Y., Rebello M. and Wang J. - 2009 - Private Information and Bargaining Power in Venture Capital Financing SECOND ANNUAL RESEARCH SYMPOSIUM ON ECONOMICS AND LAW OF THE ENTREPRENEUR - Boston University School of Management Research Paper series No. 2009-02 - Journal of Economics and Management Strategy, Forthcoming

Lerner J. - 2002 - Boom and Bust in the Venture Capital Industry and the Impact on Innovation - Harvard Business School - Finance Unit; Harvard University - Entrepreneurial Management Unit; National Bureau of Economic Research (NBER) - Paper no. 03-13

Leslie A. Jeng and Phillipe C. Wells - 1998 - The Determinants of Venture Capital Funding: Evidence Across countries Metrick A. and Yasuda A. - 2010 - Venture Capital \& the Finance of Innovation - ISBN 978-0-470-45470-1

Mohammad M. and Shahwa S. - The Objective of Islamic Economic and Islamic Banking in Light of Maqasid Al-Shariah: A Critical Review - 2013 - Middle-East Journal of Scientific Research 13 (Research in Contemporary Islamic Finance and Wealth Management): 75-84 - ISSN 1990-9233

Musso P. and Schiavo S. - 2007 - The Impact of Financial Constraints on Firms Survival and Growth - Observatoire Francaise des Conjoncture Economiques

National Venture Capital Association (NVCA) YearBook Report 2012 - 2012

Peneder M. - 2010 - The Impact of Venture Capital on Innovation Behavior and Firm Growth - WIFO Working Papers, No. 363 - Venture Capital: An International Journal of Entrepreneurial Finance, Vol. 12, No. 2, pp. 83-107

Petreski M. - Journal of Entrepreneurship and Finance, Forthcoming - The Role of Venture Capital in Financing Small Businesses

Pierrakis Y. - 2010 - Venture Capital: Now and After the Dotcom Crash

Raina L. and Bakker M. R. - Non-Bank Financial Institutions and Capital Markets in Turkey - 2003 - World Bank Working Paper - 25954

Reda M. - 2012 - ENHANCING EGYPT'S COMPETITIVENESS: EDUCATION, INNOVATION AND LABOR - Malak Reda Publication of the Egyptian Center of Economic Studies - Working Paper No. 167

Reda M. - 2012 - Enhancing Egypt's Competitiveness: Education, Innovation and Labor - Working paper no. 167 - The Egyptian Center for Economic Studies

Romain A. and Pottelsberghe B. - 2003 - The Determinants of Venture Capital: A Panel Data Analysis of 16 OECD Countries - Institute of Innovation Research, Hitotsubashi University - Working Paper No. 03-25

Romain A. and Pottelsberghe B. - 2004 - The Economic Impact of Venture Capital - Studies of the Economic Research Center, Series 1, and No. 18/2004

Samila S. and Sorenson O. - 2011 - Venture Capital, Entrepreneurship, and Economic Growth - The Review of Economic and Statistics, Vol. 93, No. 1, pp. 338-349 
Schartler A. - 2003 - Driving Forces of Venture Capital Investment in Europe: A Dynamic Panel Data Analysis - Kiel Institute for World Economics - Working Paper no. 1172

Schwienbacher A. - 2005 - An Empirical Analysis of Venture Capital Exits in Europe and the United States - EFA 2002 Berlin Meetings Discussion Paper

Segarra A. and Teruel M. - 2009 - Small firms, growth and financial constraints - Catedra Innovacio Empresa

Smith D. G. - 2005 - The Exit Structure of Venture Capital - UCLA Law Review, Vol. 53, p. 315, 2005 Univ. of Wisconsin Legal Studies Research Paper No. 1005

Ueda M. and Hirukawa M. - 2003 - Venture Capital and Productivity - Unpublished working paper 'University of Wisconsin, USA. P.152-154

Ulku H. - 2004 - R\&D, Innovation, and Economic Growth - An Empirical Analysis - IMF working paper WP/04/185

Vittas D. - 1998 - The Role of Nonbank Financial Intermediaries - Publication of The Egyptian Center of Economic Studies - Working Paper No. ECES-WP31/Vittas/1998

Weidig T. - 2002 - Toward a Risk Model for Venture Capital Funds Liquidity and Performance Forecasting

Yearbook 2012 Activity Data on Fundraising, Investments and Divestments by Private Equity and Venture Capital Firms in Europe - 2012 - EVCA 